\title{
Phytoplankton assemblages in lateral lagoons of a large tropical reservoir
}

\author{
Ferrareze, $M . *$ and Nogueira, $M G$. \\ Departamento de Zoologia, Instituto de Biociências, Universidade Estadual Paulista - UNESP, \\ Campus de Rubião Júnior, CP 510, CEP 18610-000, Botucatu, SP, Brazil \\ *e-mail: mferrareze@ibb.unesp.br
}

Received April 12, 2012 - Accepted April 17, 2012 - Distributed February 28, 2013

(With 7 figures)

\begin{abstract}
This study aimed to analyse the composition and ecological attributes of the phytoplankton assemblages in four lateral lagoons and in the main channel of Rosana Reservoir (Paranapanema River, SE Brazil). Fieldwork was carried out in September and November/2004 and January, March, May and August/2005. A total of 283 taxa was identified. Zygnemaphyta was the most specious group, followed by Chlorophyta and Bacillariophyta. Higher richness, abundance and biomass were observed in the lagoons when compared with the river-reservoir sampling point, especially during the rainy period. Cryptophyceae and Bacillariophyceae dominated numerically. Cryptomonas brasiliensis Castro, Bicudo and Bicudo was the main species of the phytoplankton in terms of abundance and frequency of occurrence. The dynamics of the most important taxa are discussed and the results showed that the phytoplankton assemblages are mainly influenced by meteorological factors and nutrient availability (the main driving forces). Correlation analyses indicated that the assemblage abundance was limited by nutrient (nitrogen and phosphorus). The phytoplankton abundance influenced positively the zooplankton abundance, what indicates the prevalence of bottom-up control routes in the lateral lagoons system. The results validate the hypotheses that lateral lagoons have a prominent ecological role on the phytoplankton diversity, as already previously demonstrated for fish and zooplankton. Therefore, the incorporation of the lateral lagoons in environmental programmes should be a target strategy for the conservation of the regional aquatic biota, minimising the negative impact of the dam.
\end{abstract}

Keywords: Paranapanema River, Rosana Reservoir, Cryptophyceae, Chlorophyceae, Bacillaryophyceae.

\section{Assembleias fitoplanctônicas em lagoas laterais de um reservatório tropical de grande porte}

\section{Resumo}

O objetivo deste estudo foi analisar a composição e os atributos ecológicos das assembleias fitoplanctônicas de quatro lagoas marginais e canal principal do Reservatório de Rosana (SE, Brasil). Os trabalhos de campo foram realizados em setembro e novembro de 2004, e janeiro, março, maio e agosto de 2005. O número total de táxons identificados foi de 283. Zygnemaphyta foi o grupo com maior número de espécies, seguido por Chlorophyta e Bacillariophyta. Maior riqueza, abundância e biomassa foram observadas nas lagoas, quando comparadas ao canal do rio-reservatório, especialmente durante o período chuvoso. Cryptophyceae e Bacillariophyceae dominaram numericamente as assembleias. Cryptomonas brasiliensis Castro, Bicudo e Bicudo foi a principal espécie do fitoplâncton, em termos de abundância e frequência de ocorrência. Os resultados mostraram que as assembleias fitoplanctônicas são influenciadas principalmente pelos fatores meteorológicos e nutrientes (funções de força). Análises de correlação mostraram que a abundância do fitoplâncton foi limitada por nutrientes (nitrogênio e fósforo). Por sua vez, a abundância fitoplanctônica influenciou positivamente a abundância do zooplâncton, o que indica a predominância de mecanismos de controle ascendente no sistema de lagoas laterais. Os resultados validaram a hipótese, assim como já havia sido demonstrado para peixes e zooplâncton, de que as lagoas laterais têm um proeminente papel na diversidade do fitoplâncton. A incorporação das lagoas laterais em programas ambientais seria uma boa estratégia para a conservação da biota aquática regional, minimizando o impacto negativo do represamento.

Palavras-chave: Rio Paranapanema, Reservatório de Rosana, Cryptophyceae, Chlorophyceae, Bacillaryophyceae. 


\section{Introduction}

The construction of reservoirs causes significant physical, chemical and biological changes along the longitudinal axis of the impounded rivers (Straškraba, 1990; Barbosa et al., 1999).

Over recent years, intensive efforts have been undertaken in order to systematise studies on reservoirs in Brazil, generating significant advances in the limnological knowledge of this kind of ecosystem (e.g. Henry, 1999; Tundisi and Straškraba, 1999; Nogueira et al., 2006). The accumulated limnological data on reservoir ecology has provided a growing understanding of these systems as a unique class of lakes. However, the knowledge of the structure and functioning of reservoirs is still incomplete (Kennedy et al., 2003), specially for management purposes (Tundisi and Matsumura-Tundisi, 2003). For example, integrated approaches of the interactions between reservoirs and lateral lagoons are still scarce (Bicudo et al., 2006).

The filling up of the reservoir can increase the connectivity between river channel and floodplain habitats, or even generate the formation of lateral lagoons (Henry et al., 2006a, b). The lateral lagoons are highly productive, exhibit numerous microhabitats and are colonised by rich assemblages of plants, invertebrate and vertebrate fauna (Pieczynska, 1990; Baumgartner et al., 2004). Therefore, these environments have an important role for regional biodiversity maintenance.

Among the numerous inland water habitats colonised by algae, the lateral lagoons are peculiar as a consequence of the strong interaction with the fluvial and semi-terrestrial ecosystems (Huszar, 1996; Henry et al., 2006c). These environments have also a prominent role in the nutrient flow and in the maintenance of the trophic resources and biodiversity for the entire fluvial system (Naiman et al., 1988; Pieczynska, 1990; Wetzel and Likens, 1991; Mitsch, 1996).

Phytoplankton organisms are important for the primary productivity of freshwater ecosystems and some taxa, or their numerical proportion, are considered as indicators of different environment conditions (e.g. hydrodynamics and trophic state) (e.g. Rosén, 1981; Sommer, 1984; Vincent and Dryden, 1989; Reynolds, 1992, 1999; Padisák et al., 1999; Nogueira et al., 2010). The structure of algae assemblages (e.g. specific composition and richness, population densities, dominance and uniformity), can be used to evaluate the aquatic system quality, and the specific diversity measurements constitute an appropriate index to compare different environment conditions (Rosa et al., 1988).

Studies in the Neotropics shown the strong influence of meteorological factors, such as precipitation, winds and temperature, as well as of chemical nutrients and interactions with other aquatic communities, on variations of the composition, abundance, and biomass of phytoplankton assemblages (e.g. Santos and Calijuri, 1998; Melo and Huszar, 2000; Calijuri et al., 2002; Tundisi and MatsumuraTundisi, 2008).
In the present study the composition and ecological attributes of phytoplankton in four lateral lagoons and in the main channel of Rosana Reservoir were analysed. The specific objectives were to determine the spatial and temporal variation tendencies in the composition, richness, abundance and diversity, as well as to correlate the abundance of the phytoplankton with the limnological variables (transparency, temperature, $\mathrm{pH}$, electric conductivity of water, turbidity and concentrations of dissolved oxygen, total suspended solids, dissolved silicate and total nutrients), precipitation and zooplankton abundance.

The main hypothesis is that the lateral lagoons have a significant contribution for the phytoplankton diversity maintenance of Rosana Reservoir. A further objective was that of determining the main driving forces influencing the spatial and temporal variation of the composition and ecological attributes of the phytoplankton assemblages in the lateral lagoons system.

\section{Material and Methods}

\subsection{Study area}

The study area is located in the upstream (tail) zone of Rosana Reservoir, approximately $80 \mathrm{~km}$ above dam (Figure 1), which is located at $22^{\circ} 36^{\prime} \mathrm{S}$ and $52^{\circ} 52^{\prime} \mathrm{W}$. The reservoir is the last one of a series of eleven constructed along the Paranapanema River (SP/PR, Brazil), with a surface area of $276 \mathrm{~km}^{2}$ (watershed of $11,000 \mathrm{~km}^{2}$ ), water retention time of 21 days (annual mean value), relatively shallow (maximum of $26 \mathrm{~m}$ close to the dam) and exhibits an oligo-mesotrophic condition (Nogueira et al., 2006).

The climate is subtropical humid with pronounced dry and rainy seasons. During the study period, the rainy season ranged from September/2004 to January/2005 (month average of $157 \mathrm{~mm}$ ). The dry period was exceptionally long, from February to August of 2005 (month average of $70.7 \mathrm{~mm}$ ). The seasonal accumulated rain precipitation in the study period was $1,207.5 \mathrm{~mm}$. The rain precipitation data was provided by the meteorological station of the State Park of "Morro do Diabo", municipality of Teodoro Sampaio (state of São Paulo).

\subsection{Samplings and laboratory analyses}

Fieldwork was carried out in September and November/2004 and January, March, May and August/2005. Samplings were performed in 4 lagoons and one sampling station in the Paranapanema River (PR), close to the river bank (Figure 1).

Two kinds of lagoons were assessed: 3 natural systems - FPB, FPC and FPD, and one originated by the flood of dredging areas, FPA. The natural lagoons FPB and FPD are located inside the State Park of "Morro do Diabo", while the FPC is located in an area influenced by human activities (agriculture and cattle breeding). The dominant macrophytes of each lagoon were registered (Table 1). Identification of these plants was performed at the genus level, with help of taxonomists of Botany 


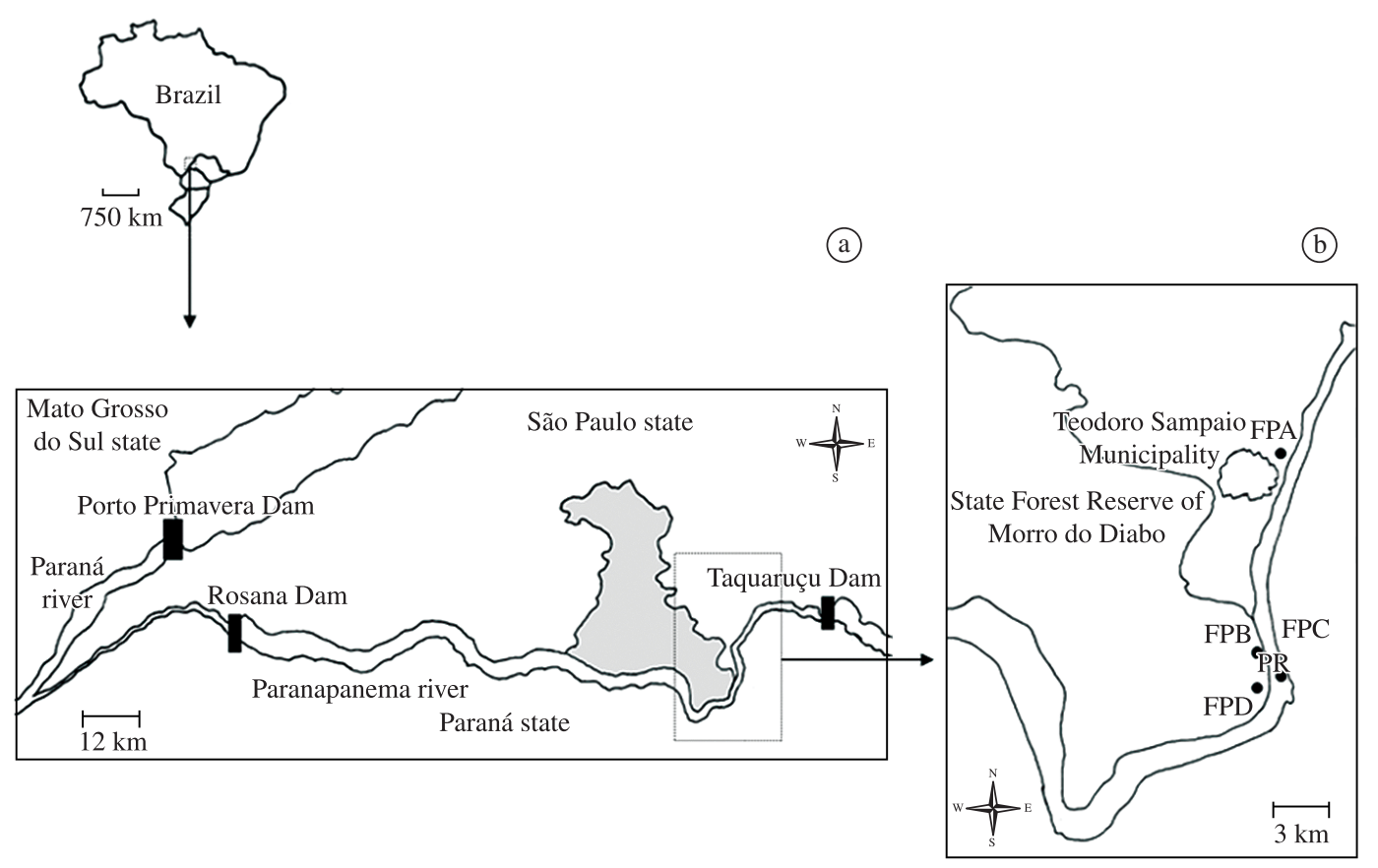

Figure 1. Study area in the region of the confluence of Paraná and Paranapanema Rivers (states of São Paulo - SP, Paraná - PR and Mato Grosso do Sul - MS) showing the positioning of Rosana, Taquaruçu and Porto Primavera dams and the State Forest of "Morro do Diabo" (gray area) (a). On the right (detail) the location of the sampling stations and the municipality of Teodoro Sampaio (b).

Table 1. Significant $(r>0.4)$ correlations of the biotic and abiotic variables with the main components 1 e 2 (CCA analysis).

\begin{tabular}{lcc}
\hline & r (Axis 1) & r (Axis 2) \\
\hline \multicolumn{1}{c}{ Biotic } & & \\
Bacilariophyceae & 0.9 & -0.03 \\
Chlorophyceae & -0.5 & -0.7 \\
Chrysophyceae & 0.4 & 0.06 \\
Zygnemaphyceae & -0.4 & -0.2 \\
Cyanophyceae & -0.5 & 0.7 \\
Cryptophyceae & -0.4 & 0.01 \\
\hline \multicolumn{1}{c}{ Abiotic } & & \\
Total Nitrogenous & -0.5 & 0.1 \\
Total Phosphorus & -0.4 & -0.4 \\
Dissolved silicate & 0.3 & -0.6 \\
Rain precipitation & -0.6 & 0.4 \\
pH & 0.7 & 0.03 \\
Dissolved oxygen & 0.4 & -0.2 \\
Temperature & -0.8 & -0.3 \\
Transparency & 0.8 & -0.03 \\
Turbidity & -0.7 & 0.3 \\
Total Suspended Solids & -0.5 & 0.4 \\
\hline
\end{tabular}

Department from Biosciences Institute of UNESP/Botucatu. Additional information of this lagoon system is provided by Ferrareze and Nogueira (2011a, b).
The sampling stations positioning, the area of each lagoon (integration of geometric distances), as well as their connectivity (transversal section of the lagoon mouth) with the river-reservoir main channel, were determined using a Garmin E-Trex GPS.

Unfiltered samples were collected at the subsurface (ca. $0.5 \mathrm{~m}$ ) and fixed with Lugol solution for the phytoplankton quantitative analysis. After sedimentation (Margalef, 1983), the individuals (cell, colony, and filament) were counted using inverted microscopy (Utermöhl, 1958) at a magnification of 400×. At least 120 optical fields distributed in parallel transects (minimum of 150 organisms) were considered per sample. Additional samples, specially used for richness determination, were also collected through vertical net hauls ( $20 \mu \mathrm{m}$ of mesh size) from near bottom (ca. $0.5 \mathrm{~m}$ ) to surface and preserved in $4 \%$ formalin. These samples were analysed in optical microscope (maximum magnification of $1000 \times$ ) for the identification of the phytoplankton organisms. Bicudo and Menezes (2005) was used as basic reference (genus level).

As an indicator of the phytoplankton biomass, chlorophyll $a$ (total) concentration was determined after filtration (Millipore AP40 membranes) of $1000 \mathrm{~mL}$ of water from each sampling point (sub surface). For pigments extraction, it was used cold acetone (90\%) and manual maceration (Golterman et al., 1978).

Phytoplankton diversity was estimated using the Shannon-Weaver Index $\left(\log _{2}\right)$. In order to compare the 
sampling sites, using the phytoplankton structure assemblages, a cluster analysis (r-Pearson similarity) (Pcordwin) was performed. The organism abundance per class was used, as each one constitutes a well defined ecological group indicating distinct environmental conditions (Reynolds, 1984).

The mean values of the assemblages attributes were calculated in order to synthesize the information and facilitate the identification of spatial and temporal patterns. Data were grouped considering two periods: rainy and dry. The representativeness of the means was assumed based on the data normal distribution (Shapiro-Wilk's W test) (Statistica TM 6.0).

A one-way ANOVA test was performed to detect differences among sampling sites. When differences were detected, the Tukey test was applied to determine the level of significance. Differences between periods were verified by the t-student test, using the variables mean values for each season (dry and rainy). Significant differences were considered when $\mathrm{p}<0.05$, which are mentioned in the results presentation. The analyses were performed using the StatisticaTM 6.0 software (Statsoft, 2001).

Finally, two different multivariate analyses were used in order to test the postulated hypothesis and to identify the main factors influencing on the phytoplankton biomass/ abundance. The canonic correspondence analysis, CCA (Pcordwin) (McCune and Mefford, 1999) was used to verify correlations between the phytoplankton groups and the limnological variables, per sampling site and sampling period. A cluster analysis (r-Pearson similarity) (Pcordwin) was performed to compare the similarity of the phytoplankton structure among the distinct sampling places.

Additionally a correlation analysis (Pearson productmoment) (Sokal and Rohlf, 1979) was performed to determine the degree of association between the different environmental variables (total nitrogen and phosphorus, chlorophyll $a$, transparency, dissolved phosphorus and zooplankton abundance) and the phytoplankton assemblages. Data on environmental variables were provided by Ferrareze et al. (in press).

\section{Results}

A total of 283 taxa was registered, distributed in 103 different genera. Zygnemaphyta was the most specious group (94 taxa), followed by Chlorophyta (77 taxa), Bacillariophyta (71 taxa), Cyanophyta (20 taxa), Euglenophyta (12 taxa), Chrysophyta (5 taxa), Dinophyta (2 taxa), Cryptophyta (1 taxa) and Xanthophyta (1 taxa).

Significant higher phytoplankton richness was observed in the lateral lagoons when compared with the river-reservoir sampling station $(\mathrm{p}=0.000021 ; \mathrm{F}=236.84)$ (Figure 2). The FPD exhibited the highest phytoplankton richness (varying from 70 to 100 species per period). Seasonally, significant higher richness was observed during rainy season (93 taxa) compared to the dry period (76 taxa) $(p=0.004)$.

The lateral lagoons showed significant higher phytoplankton abundance when compared with the

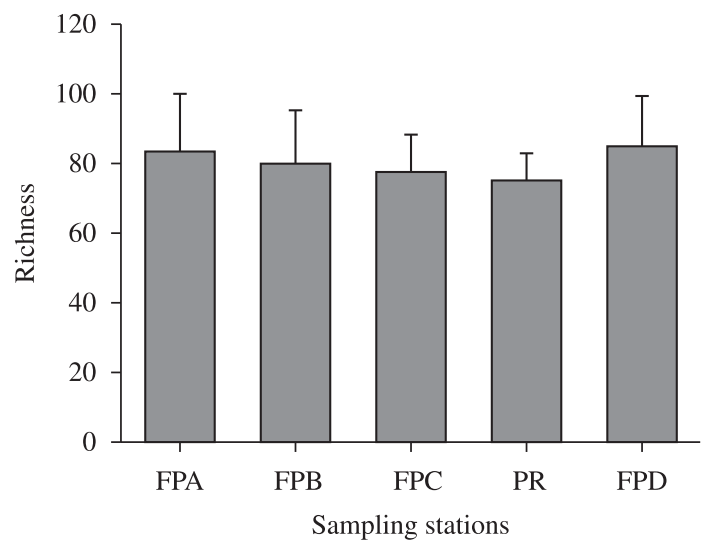

Figure 2. Phytoplankton richness (mean values and standard deviation) at the different sampling stations.

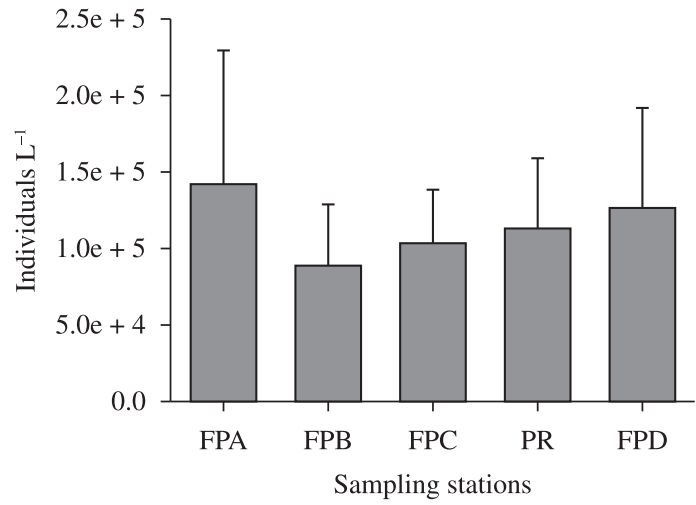

Figure 3. Phytoplankton abundance (mean values and standard deviation) at the sampling stations, considering the different study periods.

reservoir ( $p=0.0000 ; F=117.86$ ) (Figure 3). However, in two lagoons (FPB and FPC) the lowest number of individuals during the sampling carried out in November of 2004 was found (values of 46,992 and 63,694 individual $\mathrm{L}^{-1}$, respectively). Seasonally, significant higher abundance was observed in rainy (mean of 135,760 individual $\mathrm{L}^{-1}$ ) compared to the dry period (mean of 93,623 individual $\left.\mathrm{L}^{-1}\right)(\mathrm{p}=0.041)$.

The phytoplankton abundance was positively correlated with the total dissolved phosphorus $(r=0.45 ; \mathrm{p}=0.003)$, total nitrogen $(r=0.58 ; \mathrm{p}=0.001)$ and zooplankton abundance $(r=0.8 ; p=0.000)$, but the phytoplankton abundance exhibited a poor correlation with the total phosphorus $(\mathrm{r}=0.18 ; \mathrm{p}=0.04)$.

The phytoplankton biomass (chlorophyll a) had the same variation pattern exhibited by the abundance. Highest values of biomass occurred in the lateral lagoons ( $\mathrm{p}=0.00$; $\mathrm{F}=94.02$ ) (Figure 4), although the lowest average values for chlorophyll were measured at FPB and FPC stations. Seasonally, significant higher biomass was also observed 
in the rainy (mean of $3.21 \mu \mathrm{g} \mathrm{L}^{-1}$ ) compared to the dry period (mean of $\left.2.15 \mu \mathrm{g} \mathrm{L}{ }^{-1}\right)(\mathrm{p}=0.049)$.

A positive linear correlation between chlorophyll and phytoplankton numerical abundance was determined $(\mathrm{r}=0.98 ; \mathrm{p}=0.001)$. Chlorophyll $a$ was negatively correlated with transparency $(r=0.6 ; \mathrm{p}=0.0011)$.

The relative abundance among the main phytoplankton groups, for the whole study period, is shown in Figure 5. The Zygnemaphyceae, despite having a larger number of species, were not numerically dominant. Cryptophyceae was the most abundant group (41.9\%), followed by Bacillariophyceae (28.1\%). Cryptophyceae exhibited higher dominance during the rainy period, mainly in November of 2004 , corresponding to $55 \%$ of the phytoplankton density. A conspicuous presence of Bacillariophyta occurred during the dry period, with $48.3 \%$ of the phytoplankton in August

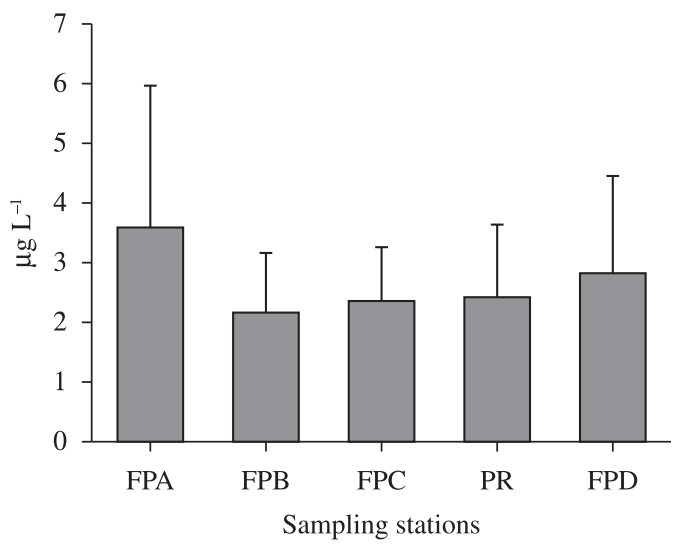

Figure 4. Phytoplankton biomass (chlorophyll a) (mean values and standard deviation) at the sampling stations, considering the different study periods.

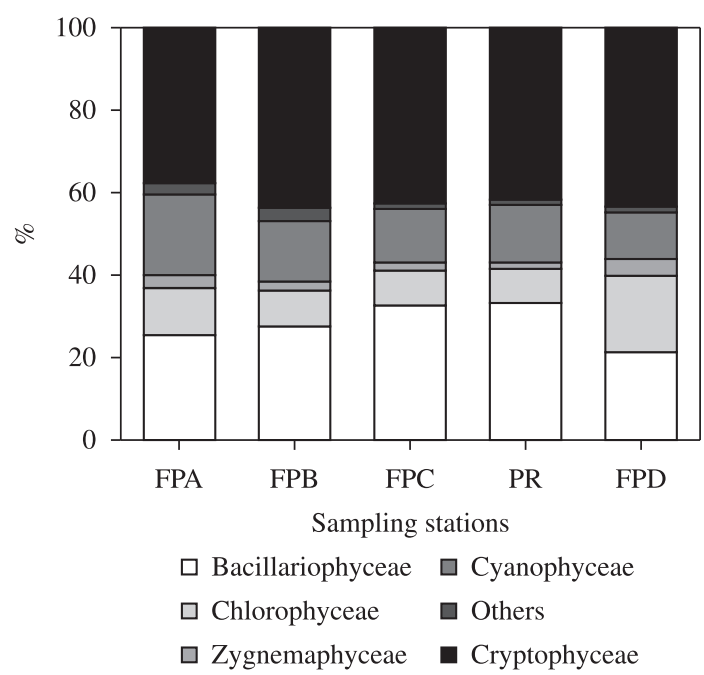

Figure 5. Relative abundance among the phytoplankton groups at the different sampling stations, considering the different study periods. of 2005. Chlorophyta had a relatively higher contribution only in the autumn (May of 2005). In this sampling period, the abundance distribution among the different main phytoplankton groups was more homogeneous. Cyanophyta had higher density during summer (January of 2005). The highest percentage of this group occurred in the FPA station.

The species Cryptomonas brasiliensis Castro, Bicudo and Bicudo can be considered as the main species of the phytoplankton in this study. The specie was observed in all samples and its abundance ranged from $21 \%$, in FPA (September of 2004), to 62.3\%, in FPC (November of 2004).

Despite the higher phytoplankton diversity (mean values) in the lateral lagoons, when compared with the river-reservoir sampling station, there was no significant difference among the sampling stations $(\mathrm{p}=0.683 ; \mathrm{F}=0.575)$ (Figure 6). There was also no significant difference between the seasonal periods $(\mathrm{p}=0.07)$ for this attribute.

The cluster analysis, on the basis of the phytoplankton assemblage structure of each sampling station, showed a higher similarity between FPC and PR (Figure 7).

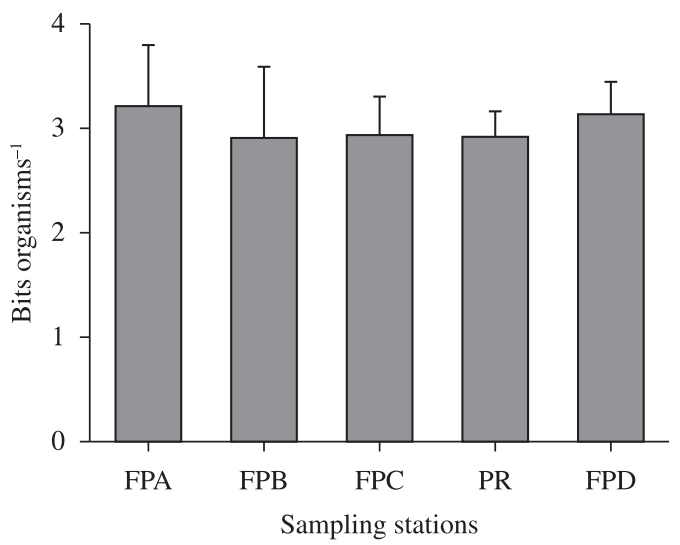

Figure 6. Diversity of the phytoplankton assemblages (mean values and standard deviation) at the sampling stations, during the different study periods.

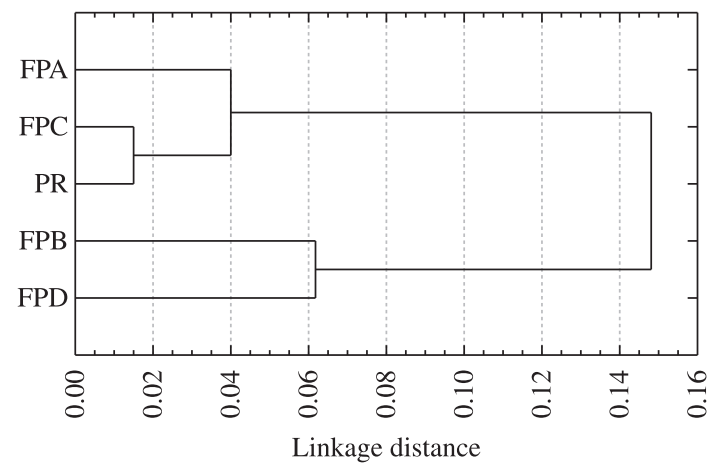

Figure 7. Similarity analysis among the sampling stations based on the abundance of the phytoplankton classes. 
The analysis also evidenced that the most distinctive environments were the FPB and FPD, which are located inside the State Park of "Morro do Diabo" and are the most preserved lagoons.

Finally, the results of the CCA (Table 1) explained $67 \%$ of the data variability $(\mathrm{p}=0.02)$, considering the three first ordination axes (axis $1=45 \%$, axis $2=15 \%$ and axis $3=7 \%$ ). The classes Bacillariophyceae and Chrysophyceae were better correlated with the positive side of the axis 1 , associated to low values of total nitrogen, total phosphorus, precipitation, temperature, turbidity and suspended solids and with high values of $\mathrm{pH}$, transparency and dissolved oxygen. The classes Chlorophyceae, Zygnemaphyceae, Cyanophyceae and Cryptophyceae were positioned on the negative side of the axis 1 , associated with high values of total nitrogen, total phosphorus, precipitation, temperature, turbidity and suspended solids.

Chlorophyceae was located on the negative side of the axis 2 , associated with low precipitation and with high concentrations of total phosphorus and dissolved silicate.

Some associations among the periods and the phytoplankton assemblages could be observed through the CCA analysis. The representativeness of Bacillariophyceae and Chrysophyceae increased during the dry period (September/2004, May and August of 2005). Cyanophyceae were more representative during November/2004 and January/2005, and Chlorophyceae, Zignemaphyceae and Euglenophyceae during March/2005. Cryptophyceae were not associated with any particular period, exhibiting a high abundance during the whole study.

\section{Discussion}

The contribution of lateral habitats such as lagoons, floodplains and oxbow lakes has been considered as very important for the biodiversity maintenance of the whole river watershed (Naiman et al., 1988; Pieczynska, 1990; Wetzel and Likens, 1991; Mitsch, 1996). This assumption is corroborated by the present investigation. The phytoplankton richness registered in the Rosana reservoir lateral lagoons (283 taxa/103 genera) is higher than the ones verified in other studies carried out in lotic and lentic (reservoirs) stretches sampled along the entire Paranapanema basin (Ferrareze and Nogueira, 2006; Nogueira et al., 2010) were Rosana reservoir is located. The present data on phytoplankton richness data is also higher when compared to other studies on phytoplankton assemblages carried out in particular aquatic environments of the basin with similar number of analysed samples (Nogueira, 2000; BittencourtOliveira, 2002; Bicudo et al., 2006; Henry et al., 2006c). The same pattern is verified for the zooplankton (Ferrareze and Nogueira, 2011a) and fish (Ferrareze and Nogueira, 2011b) assemblages, which were simultaneously sampled in the same environments of this study.

The results also showed that the phytoplankton assemblages exhibit considerable seasonal changes. Variations in the composition, abundance, and biomass were influenced by meteorological factors, such as precipitation and temperature, and by some important nutrients, such as total nitrogen and dissolved phosphorus. Similar tendencies were observed in others reservoirs and fluvial systems of the high Paraná River basin (Santos and Calijuri, 1998; Nogueira, 2000; Gomes and Miranda, 2001; Calijuri et al., 2002; Matsumura-Tundisi and Tundisi, 2005).

The CCA analysis clearly separated the sampling stations along the studied periods, showing the dominance of different phytoplankton classes under influence of particular limnological conditions. Through the CCA and regression analyses results, the main driving forces influencing the composition and ecological attributes of the phytoplankton assemblages in the lateral lagoons system could be inferred.

Zygnemaphyceae was the most specious phytoplankton group, followed by Bacillaryophyceae and Chlorophyceae. This structural characteristic seems to be a consistent pattern for the phytoplankton assemblages in the floodplain lagoons of the high Paraná River basin (Rodrigues and Bicudo, 2001). High richness of Bacillaryophyceae and Chlorophyceae has also been observed for three lateral lagoons of the upper Paranapanema River basin (Jurimirim reservoir tail zone) (Henry et al., 2006a), and for the Paranapanema River reservoir cascade (Nogueira et al., 2010). Another factor influencing the high richness of Zygnemaphyceae in the lateral lagoons is the contribution of the periphyton assemblages, due to the high abundance of different species of aquatic macrophytes, microhabitats highly propitious for the development of attached algae (Tundisi and Matsumura-Tundisi, 2008).

Higher abundance and biomass (chlorophyll $a$ ) of phytoplankton assemblages were observed in the lateral lagoons, compared to the reservoir. This is a result of nutrient availability verified in these environments, especially during the rainy period (late spring and summer) (Ferrareze et al., in press). The seasonal input of nutrients, associated to the instability of the water column (strong rains; increased flow), resulted in dominance of C-strategist species, such as Cryptomonas and Discotella, or even r-strategists, such as Aulacoseira spp., typical of the initial phase of succession (Reynolds, 1984).

Positive correlation among phytoplankton assemblages and nutrient concentration during the high water period was also observed by other authors in the upper Paraná River basin (Train and Rodrigues, 1998; Rodrigues and Bicudo, 2001) and in the Paranapanema River Basin (Nogueira, 2000; Bittencourt-Oliveira, 2002; Henry et al., 2006a; Ferrareze and Nogueira, 2006; Bicudo et al., 2006; Nogueira et al., 2010).

Different from isolated natural lakes, phytoplankton dynamics in rivers is dominated by physical forces, and those biotic interactions traditionally believed to regulate limnetic communities are suppressed and rarely wellexpressed (Reynolds et al., 1994).

The results of the correlation analysis indicate that the phytoplankton abundance in Rosana Reservoir and lateral lagoons can be limited by nitrogen and phosphorus. It was also shown, and the same was found by Nogueira et al. (2010) for the Paranapanema reservoirs cascade, that the 
zooplankton does not control the phytoplankton abundance. These results indicated that in the studied lateral lagoons the communities are mainly controlled by bottom-up mechanisms.

In general, the chlorophyll concentrations in the studied areas were low. According to Miranda and Gomes (2001), an important factor responsible for the recurrent low values of chlorophyll in the upper Paraná basin reservoirs is the predominant high flow, in addition to the scarcity of some important mineral nutrients, other than $\mathrm{N}$ and $\mathrm{P}$, and minor essential ions such as carbon, potassium, calcium, magnesium and iron.

The increase in chlorophyll concentration associated to higher transparency (dry period) has been found in several tropical/subtropical rivers and lagoons (Schimidt, 1970; Rai and Hill, 1982; Bonetto et al., 1983; Bonetto, 1986; Garcia de Emiliani, 1990; Neiff, 1990; Carvalho et al., 2001). However, in the present study, despite of a drastic reduction of the water transparency in the rainy period, there was an increase in the chlorophyll concentrations. The same pattern was verified for other reservoirs and fluvial stretches in the Paranapanema River Basin (Ferrareze and Nogueira, 2006; Nogueira et al., 2010). This fact is due to the growth of phytoplankton groups tolerant to the low light penetration, such as Cryptophyceae and some species of diatoms. The increase in chlorophyll was determined by higher nutrient concentrations in the lagoons (Ferrareze et al., in press) and by the enhancement in the water flux, favouring some species of Bacillariophyceae, such as the ones of the genus Aulacoseira, and Cryptopheceae (functional group Y, C-strategist, sensu Reynolds et al., 2002), able to develop abundant populations under more turbulent conditions (Happey-Wood, 1988; Tundisi and Matsumura-Tundisi, 1990).

Therefore, the negative correlation between water transparency and chlorophyll shows that the light conditions in the Rosana Reservoir seems not to be a limiting factor for the phytoplankton growth. These results demonstrate that these assemblages responded quickly to the environmental variations, as proposed by Reynolds (1984).

The instability of the water column promoted by the rainfall, the relatively low water retention time of the reservoir (ca. 20 days) and the high input of nutrients could explain the small changes in the phytoplankton assemblages dominance during the studied period. These conditions can restrict a wide number of phytoplankton species to succeed and favor the Cryptophyceae (C-strategist). Only during few periods some genera, such as Aulacoseira and Discotella, experienced a higher growth.

Discotella is dominant in oligotrophic environments with great availability of light and a low Si:P ratio, if compared to other diatom groups, such as the Pennales. The Aulacoseira populations tend to be dominant in conditions of total circulation, due to the fact that their heavy frustules has high sedimentation rate and need to be continuously resuspended to remain in the water column (Wolin and Duthie, 1999). According to Reynolds (1984) and Sommer (1988) dense diatom populations occur during periods with high availability of nutrients and good light conditions and they grow quickly, mainly in the presence of high concentrations of nitrogen. These algae are considered as opportunists and colonisers (r-strategists and C-strategists). Such characteristics contribute to explain the high density of Bacillariophyceae in the river/reservoir sampling station when compared to the lateral lagoons.

The relative increase of Cyanophycea during summer is related to the growth of Microcystis aeruginosa (Kutzing) Lemmermannin. This is an S-strategist species, specialist in phosphate storage and able to regulate efficiently its vertical positioning. Microcystis requires high temperatures, tolerate variation in light intensity and it is not vulnerable to predation by herbivorous zooplankton (Kilham and Hecky, 1988).

The increase of Euglenophyceae during summer, mainly in the lateral lagoons, is probably due to the organic matter carried by the rainfall, typical of this period, from the terrestrial system to the aquatic system. This group of organism can make facultative use of dissolved organic matter in nutritious processes (Reynolds, 1984).

The variation of the phytoplankton diversity was not significantly different among sampling stations and periods, due to the continuous Cryptomonas numerical dominance. The diversity values were similar to the ones calculated in other studies carried out in the Paranapanema basin (Nogueira, 2000; Bittencourt-Oliveira, 2002; Bicudo et al., 2006; Ferrareze and Nogueira, 2006; Henry et al., 2006c; Nogueira et al., 2010).

The degree of similarity among phytoplankton assemblages sampled in the different sites (cluster analysis), shows the importance of the interaction between the surrounding landscape and the aquatic environments (Huszar, 1996; Henry, 2003). The lateral lagoons located inside the State Park of "Morro do Diabo" exhibited more distinct assemblages than the other lagoons. Additionally, the analysis also evidenced the influence of the river phytoplankton on the assemblages of the widely connected lateral lagoon, FPC. The same pattern is observed for zooplankton (Ferrareze and Nogueira, 2011a), fish (Ferrareze and Nogueira, 2011b) and nutrients (Ferrareze et al., in press).

Our study demonstrates the importance of considering the lateral lagoons and other similar wetland habitats for the biodiversity assessment in water basins. The hypothesis that lateral lagoons have a prominent ecological role for the phytoplankton of Rosana Reservoir, exporting diversity for the whole river system, was validated. The main driving forces influencing the composition and the ecological attributes of the assemblages in the lateral lagoons system were also evidenced. Therefore the incorporation of the lateral lagoons should be a target strategy for the conservation of the regional aquatic biota, minimising the negative impact of dam construction.

Acknowledgements - The authors are grateful to CNPq for the scholarship conceded to the first author; to Duke Energy International Geração Paranapanema and to the Fundação do Instituto de Biociências (Fundibio) for the financial and administrative support, respectively.

\section{References}

BARBOSA, FAR., PADISAK, J., ESPINDOLA, ELG., BORICS, G. and ROCHA, O., 1999. The cascading reservoir continuum 
concept (CRCC) and its application to the river Tietê-Basin, São Paulo State, Brazil. In TUNDISI, JG. and STRASKRABA, M. (Eds.). Theoretical Reservoir Ecology and its Applications. Leiden: Brazilian Academy of Sciences, International Institute of Ecology and Backhuys Publishers. p. 425-437.

BAUMGARTNER, G., NAKATANI, K., GOMES, LC., BIALETZKI, A., SANCHES, PV. and MAKRAKIS, MC., 2004. Identification of spawning sites as natural nurseries in the Upper Paraná River. Environmental Biology of Fish, vol. 71, p. 115-125.

BICUDO, CEM. and MENEZES, M., 2005. Gêneros de algas de águas continentais do Brasil: chave para identificação e descrições. São Carlos: RiMa Editora. 489 p.

BICUDO, DC., FERRAGUT, C., CROSSETTI, LO. and BICUDO, CEM., 2006. Efeitos do represamento sobre a estrutura da comunidade fitoplanctônica do Reservatório de Rosana, baixo rio Paranapanema, Estado de São Paulo. In NOGUEIRA, MG., HENRY, R. and JORCIN, A. (Eds.). Ecologia de reservatórios: impactos potenciais, ações de manejo e sistemas em cascata. 2. ed. São Carlos: RiMa Editora. p. 349-377.

BITTENCOURT-OLIVEIRA, MC., 2002. A comunidade fitoplanctônica do Rio Tibagi: uma abordagem preliminar de sua diversidade. In MEDRI, ME., BIANCHINI, E., SHIBATTA, OA. and PIMENTA, JA. (Eds.). A bacia do rio Tibagi. Londrina: Universidade Estadual de Londrina. p. 373-402.

BONETTO, AA. 1986. The Paraná River System. In DAVIES, BR. and WALKER, KF. (Eds.) The ecology of River Systems. Dordrecht: Dr. W. Junk Publishers. p. 541-555.

BONETTO, AA., ZALOCAR DE DOMITROVIC, Y. and VALLEJOS, ER., 1983. Fitoplancton y producción primaria del rio Alto Paraná (Argentina). Physis, vol. 41, no. 101, p. 81-93.

CALIJURI, MC., DOS SANTOS, ACA. and JATI, S., 2002. Temporal changes in the phytoplankton community structure in a tropical and eutrophic reservoir (Barra Bonita, SP - Brazil). Journal of Plankton Research, vol. 24, no. 7, p. 617-634. http:// dx.doi.org/10.1093/plankt/24.7.617

CARVALHO, P., BINI, LM., THOMAZ, SM., GONÇALVES, LG., ROBERTSON, B., TAVECHIO, WLG. and DARWISCH, AJ., 2001. Comparative limnology of South American floodplain lakes and lagoons. Acta Scientiarum, vol. 23, no. 2, p. 265-273.

SANTOS, ACA. and CALIJURI, MC., 1998. Survival strategies of some species of the phytoplankton community in the Barra Bonita reservoir (São Paulo, Brazil). Hydrobiologia, vol. 367, p. 139-152. http://dx.doi.org/10.1023/A:1003276016149

FERRAREZE, M. and NOGUEIRA, MG., 2006. Phytoplankton assemblages in lotic systems of the Paranapanema Basin (Southeast Brazil). Acta Limnologica Brasiliensia, vol. 18, no. 4, p. 389-405.

-, 2011a. Importance of lateral lagoons for the zooplankton assemblages (Cladocera and Copepoda) in a large tropical reservoir. Oecologia Australis, vol. 15, no. 3, p. 673-687.

-, 2011b. Importance of lateral lagoons for the ichthyofauna in a large tropical reservoir. Brazilian Journal of Biology, vol. 70, no. 4 , p. 1-14.

FERRAREZE, MF., NOGUEIRA, MG. and SARTOTI, LP. In press. Limnology of lateral lagoons in a tropical reservoir (SE Brazil) - spatial and temporal variability. Limnetica.

GARCIA DE EMILIANI, MO., 1990. Phytoplankton ecology of the middle Paraná River. Acta Limnologica. Brasiliense, vol. 3, p. 391-417.
GOLTERMAN, HL., CLYMO, RS. and OHSTAD, MA., 1978. Methods for physical and chemical analysis of fresh waters. 2nd. ed. Oxford: Blackweel Scientific Publications. 213 p.

GOMES, LC. and MIRANDA, LE., 2001. Hydrologic and climatic regimes limit phytoplankton biomass in reservoirs of the Upper Paraná River Basin, Brazil. Hydrobiologia, vol. 457, p. 205-214. http://dx.doi.org/10.1023/A:1012295901870

HAPPEY-WOOD, CM., 1988. Ecology of freshwater planktonic green algae. In SANDGREEN, CD. (Ed.). Growth and reproductive strategies of freshwater phytoplankton. Cambridge: Cambridge University Press. p. 175-226.

HENRY, R. 1999. Ecologia de Reservatórios: Estrutura, função e aspectos sociais. Botucatu: FAPESP, FUNDIBIO. $632 \mathrm{p}$.

HENRY, R., 2003. Os ecótonos nas interfaces dos ecossistemas aquáticos: conceitos, tipos, processos e importância. Estudo de aplicação em lagoas marginais ao Rio Paranapanema na zona de sua desembocadura na Represa Jurumirim. In HENRY, R. (Ed.). Ecótonos nas interfaces dos ecossistemas aquáticos. São Carlos: Rima Editora. p. 1-28. http://dx.doi.org/10.1590/S151969842006000200008

HENRY, R., NOGUEIRA, MG., POMPÊO, MLM. and MOSCHINICARLOS, V., 2006a. Annual and short-term variability on primary productivity by phytoplankton and correlated abiotic factors in Jurumirim Reservoir (São Paulo, Brazil). Brazilian Journal of Biology, vol. 66, no. 1b, p. 239-261.

HENRY, R., PANARELLI, EA., CASANOVA, SMC., SUIBERTO, M., AFONSO, AAO., 2006b. Interações hidrológicas entre lagoas marginais e o Rio Paranapanema na zona de sua desembocadura na Represa de Jurumirim. In NOGUEIRA, MG., HENRY, R. and JORCIN, A. (Eds.). Ecologia de Reservatórios: Impactos potenciais, ações de manejo e sistemas em cascata. São Carlos: Rima Editora. p. 57-82.

HENRY, R., USHINOHAMA, E. and FERREIRA, RAR., 2006c. Fitoplâncton em três lagoas marginais ao Rio Paranapanema e em sua desembocadura no Reservatório de Jurumirim (São Paulo, Brasil) durante um período prolongado de seca. Revista Brasileira de Botânica, vol. 29, p. 399-414. http://dx.doi.org/10.1590/ S0100-84042006000300007

HUSZAR, VLM., 1996. Floristic composition and biogeographical aspects of phytoplankton of an Amazoniana flood-plain lake (Lago Batata, Pará, Brasil). Acta Limnologica Brasiliensia, v. 6 , p. $127-136$

KENNEDY, RH., TUNDISI, JG., STRASKRABA, V., LIND, OT. and HEJZLAR, J., 2003. Reservoirs and the limnologist's growing role in sustainable water resource management. Hydrobiologia, vol. 504, p. xi-xii.

KILHAM, P. and HECKY, RE., 1988. Comparative ecology of marine and freshwater phytoplankton. Limnology Oceanograph, vol. 33, p. 776-795. http://dx.doi.org/10.4319/lo.1988.33.4 part_2.0776

MARGALEF, R., 1983. Limnologia. Barcelona: Omega S.A. 1010 p.

MATSUMURA-TUNDISI, T. and TUNDISI, JG., 2005. Plankton richness in a eutrophic reservoir (Barra Bonita Reservoir, SP, Brazil). Hydrobiologia, vol. 542, p. 367-378. http://dx.doi. org/10.1007/s10750-004-9461-0

McCUNE, B. and MEFFORD, MJ., 1999. PC-ORD for windows: multivariate analysis of ecological data. version 4.1 Oregon: MjM Software Design.

MELO, S. and HUSZAR, VLM., 2000. Phytoplankton in Amazonian floodplain lake (Lago Batata, Brasil): diel variation 
and species strategies. Journal of Plankton Research, vol. 22, p. 63-76. http://dx.doi.org/10.1093/plankt/22.1.63

MITSCH, WJ., 1996. Manging the world's wetlands - Preserving and enhancing their ecological functions. Verhandlungen des Internationalen Verein Limnologie, vol. 26, p. 139-147.

NAIMAN, RJ., DÉCHAMPS, H., PASTOR, J. and JOHNSTON, CA., 1988. The potencial importance of boundaries to fluvial ecosystems. Journal of North American Benthology Society, vol. 7, no. 4, p. 289-306. http://dx.doi.org/10.2307/1467295

NEIFF, JJ., 1990. Aspect of primary productivity in the lower Paraná and Paraguay riverine system. Acta Limnologica Brasiliensis, vol. 3, p. 77-113.

NOGUEIRA, MG., 2000. Phytoplankton composition, dominance and abundance as indicators of enviromental compartmentalization in Jurumirim Reservoir (Paranapanema River), São Paulo, Brazil. Hydrobiologia, vol. 431, p. 115-128. http://dx.doi. org/10.1023/A:1003769408757

NOGUEIRA, MG., JORCIN, A., VIANNA, NC. and BRITTO, YCT., 2006. Reservatórios em cascata e os efeitos na limnologia e organização das comunidades bióticas (fitoplâncton, zooplâncton e zoobentos) - um estudo de caso no rio Paranapanema. In NOGUEIRA, MG., HENRY, R. and JORCIN, A. (Eds.). Ecologias de reservatórios: impactos potenciais, ações de manejo e sistema em cascata. São Carlos: Rima Editora. cap. 4, p. 83-125.

NOGUEIRA, MG., FERRAREZE, M., MOREIRA, ML. and GOUVÊA, RM., 2010. Phytoplankton assemblages in a reservoir cascade of a large tropical - subtropical river (SE, Brazil). Brazilian Journal of Biology, vol. 70, no. 3 (supplemento), p. 781-793.

PADISÁK, J., KÖHLER, J. and HOEG, S., 1999. The effect of changing flushing rates on development of late summer Aphanizomneon and Microcystis populations in a shallow lake, Müggelsee, Berlin, Germany. In TUNDISI, JG. and STRASKRABA, M. (Eds.). Theoretical Reservoir Ecology and its Applications. Leiden: Brazilian Academy of Sciences, International Institute of Ecology and Backhuys Publishers. p. 411-423.

PIECZYNSKA, E., 1990. Littoral habitats and communities. Guidelines of Lake Management, vol. 3, p. 39-71.

RAI, H. and HILL, G., 1982. Establishing the patterns of heterotrophic bacterial activity in three central Amazonian lakes. Hydrobiologia, vol. 86, p. 121-126. http://dx.doi.org/10.1007/BF00005798

REYNOLDS, CS., 1984. The Ecology of Freshwater Phytoplankton. Cambridge: Cambridge University Press. 384 p.

-, 1992. Eutrophication and the management of planktonic algae: What Vollenweider couldn't tell us. In SUTCIFFE, DW. and JONES, JG. (Eds). Eutrophication: research and application to water supply. Ambleside: Freshwater Biological Association Publication.

-, 1999. Phytoplankton assemblages in reservoirs. In TUNDISI, JG. and STRAŚKRABA, M. (Eds.). Theoretical reservoir ecology and its applications. São Carlos. p. 439-456.

REYNOLDS, CS., DESCY, JP. and PADISÁK, J., 1994. Are phytoplankton dynamics in rivers so different from those in shallow lakes? Hydrobiologia, vol. 289, p. 1-7. http://dx.doi. org/10.1007/BF00007404

REYNOLDS, CS., HUSZAR, VLM., KRUK, C., FLORES, LN. and MELO, S., 2002. Towards a functional classification of the freshwater phytoplankton. Journal of Plankton Research, vol. 24, p. 417-428. http://dx.doi.org/10.1093/plankt/24.5.417

RODRIGUES, L. and BICUDO, DC., 2001. Limnological characteristics comparison in three systems with different hydrodynamic regime in the upper Paraná River floodplain. Acta Limnologica Brasiliensia, vol. 13, no. 4, p. 29-42.

ROSA, ZM., TORGAN, LC., LOBO, EA. and HERZOG, LAW., 1988. Análise da estrutura de comunidades fitoplanctônicas e de alguns fatores abióticos em trecho do Rio Jacuí, Rio Grande do Sul, Brasil. Acta Botanica Brasiliensis, vol. 2, no. 1-2, p. 31-46. http://dx.doi.org/10.1590/S0102-33061988000100003

ROSÉN, G., 1981. Phytoplankton indicators and their relations to certain chemical and physical factors. Limnologica, vol. 13, p. $263-290$

SANTOS, ACA. and CALIJURI, MC., 1998. Survival strategies of some species of the phytoplankton community in the Barra Bonita reservoir (São Paulo, Brazil). Hydrobiologia, vol. 367, p. 139-152. http://dx.doi.org/10.1023/A:1003276016149

SCHIMIDT, GW., 1970. Number of bacteria and algae and their interrelations in some Amazonian waters. Amazoniana, vol. 2, no. 4 , p. 393-400.

SOKAL, RR. and ROHLF, FJ., 1979. Biometría: Principios y métodos estadísticos en la investigación biológica. Madrid: Blume. 832 p.

SOMMER, U., 1984. The paradox of the plankton: flutuations os phosphorus availability maintain diversity of phytoplankton in flow-through cultures. Limnology Oceanograph, vol. 29, no. 3, p. 633-636. http://dx.doi.org/10.4319/lo.1984.29.3.0633

SOMMER, U., 1988. Growth and survival strategies of plankton succession. In SOMMER, U. (Ed.). Plankton Ecology: Succession in Plankton Communities. Springer Series in Contemporary Bioscience. p. 57-106.

StatSoft. 2001. Statistica (data analysis software system). version 6. Tulsa.

STRAŠKRABA, M., 1990. Limnological particularities of multiple reservoir series. Archiv fur Hydrobiologie Beiheft Ergebnisse der Limnologie, vol. 33, p. 677-678.

TRAIN, S. and RODRIGUES, LC., 1998. Temporal fluctuations of the phytoplankton community of the Baía River, in the upper Paraná River floodplain, Mato Grosso do Sul, Brazil. Hidrobiologia, vol. 361, p. 125-134. http://dx.doi.org/10.1023/A:1003118200157

TUNDISI, JG. and STRAŠKRABA, M., 1999. Theoretical reservoir ecology and its applications. São Carlos. 529 p.

TUNDISI, JG. and MATSUMURA-TUNDISI, T., 1990. Limnology and Eutrophication of Barra Bonita Reservoir, São Paulo State, Southern Brazil. Archiv für Hydrobiologie-Beiheft Ergebnisse der Limnologie, v. 33, p. 661-676.

,- 2003 . Integration of research and management in optimizing multiple uses of reservoirs: the experience in South America and Brazilian cases studies. Hydrobiologia, vol. 500, p. 231-242. http://dx.doi.org/10.1023/A:1024617102056

\section{-, 2008. Limnologia. São Paulo: Oficina De Texto. 745 p.}

VINCENT, WF. and DRYDEN, SJ., 1989. Phytoplankton succession and cyanobacterial dominance in a eutrophic lake of the mid-temperate zone (Lake Okaro, New Zealand). In VINCENT, WF. (Ed.) Cyanobacterial growth and dominance in two eutrophic lakes. Stuttgart. E. Schweizerbart'sche Verlagsbuchhandlung. p.137-163.

WETZEL, RG. and LIKENS, GE., 1991. Limnological analyses. 2. ed. Spring-Verlag. $391 \mathrm{p}$.

WOLIN, JA. and DUTHIE, HC., 1999. Diatoms as indicators of water level change in freshwater lakes. In: STOERMER, EF. and SMOL, JE. (Eds). The Diatoms: Application for the Environmental and Earth Sciences. Cambridge University Press. p. 183-202. 
